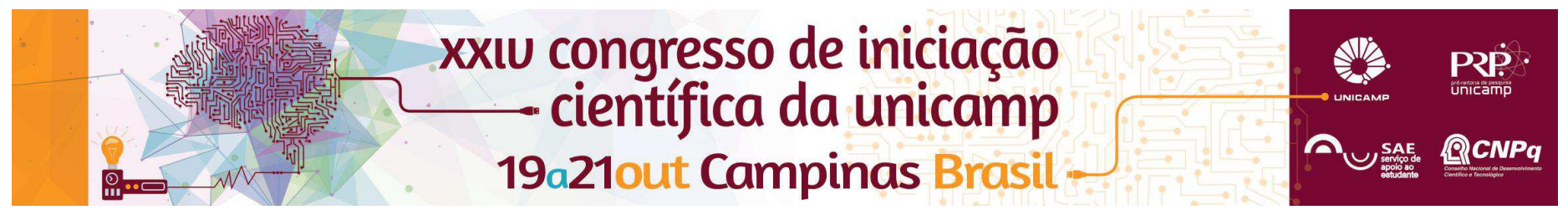

\title{
Análise dos conflitos no campo no Extremo Oeste Baiano de 2001 a 2014
}

\author{
Rhaysa Duarte Zappa*, Vicente Eudes Lemos Alves.
}

\section{Resumo}

A mesorregião do Extremo Oeste Baiano faz parte da fronteira agrícola do centro norte brasileiro. O propósito desta pesquisa foi o de pensar além da modernização e da importância da região para o agronegócio e buscar entender os conflitos que atingem o campo da região que, por sua vez, não estão dissociados da realidade agrária brasileira.

\section{Palavras-chave:}

Conflitos no campo; extremo oeste baiano, CPT.

\section{Introdução}

A mesorregião do Extremo Oeste Baiano abrange 24 municípios nas divisas com os estados do Tocantins e Goiás.

A ocupação dos cerrados baianos, segundo Alves $(2009){ }^{1}$,teve início nos anos 1970 e se consolidou nos anos de 1980. Com isso, a soja passou a ser o principal produto agrícola dos cerrados baianos, possibilitando a instalação de capital investido nas lavouras e no seu beneficiamento, e também no comércio e serviços subsidiários.

Atualmente o extremo oeste baiano faz parte da região de fronteira agrícola do centro norte brasileiro conhecida como MATOPIBA.

Dessa forma, o objetivo do trabalho foi o de averiguar os conflitos agrários que atingem a região decorrentes da modernização agropecuária nas últimas décadas.

Os tipos de conflitos no campo analisados foram: a) pela terra; b) trabalhistas (superexploração e trabalho escravo); contra a pessoa (assassinatos, tentativas de assassinatos e ameaças de morte) e c) pela água. Utilizamos, como fonte dos dados para compor o estudo, os relatórios anuais de conflitos no campo da Comissão Pastoral da Terra (CPT), referentes ao período de 2001 a 2014.

\section{Resultados e Discussão}

De acordo com os dados coletados no Relatório de Conflitos Agrários da Comissão Pastoral da Terra, o tipo de conflito no campo que mais atingiu a mesorregião do Extremo Oeste Baiano, no período de 2001 a 2014, foi o trabalhista.

Ao todo, 3424 trabalhadores foram submetidos ao trabalho escravo e, destes, 2822 foram libertados dessa condição pela fiscalização do Ministério do Trabalho e Emprego (MTE). Quanto à superexploração e desrespeito à legislação trabalhista, ocorreram 759 casos.

Os outros tipos de conflitos no campo tiveram pouca expressão, apesar de também estarem presentes. Ao todo, uma (01) pessoa foi assassinada, houve uma (01) tentativa de assassinato, cinco (05) ameaças de morte, 56 conflitos pela terra e 03 conflitos pela água (os conflitos pela água por município foram computados pela CPT até 2007, após esse ano foram divulgadas sínteses por estado da federação).

Pode-se afirmar que são múltiplas as causas do trabalho escravo no oeste da Bahia. Plassat (2014) afirma que há um ambiente político que pouco considera reconhecer e combater o trabalho escravo, criando uma possibilidade de retrocesso no combate a este crime. O grupo nacional de fiscalização móvel não consegue suprir a demanda e os fiscais atestam escassez de meios e da falta de priorização para resolução deste problema por parte dos governantes em distintas esferas. Para Sakamoto (2007), a superexploração e o trabalho escravo são utilizados em estabelecimentos em áreas de expansão que não têm a mesma capacidade de concorrer na economia globalizada. O exército de reserva de mão de obra, a grilagem e a expulsão de populações tradicionais nas áreas de fronteira agrícola aumenta o contingente de pessoas que não possuem outra opção e a não ser se submeter a péssimas condições de trabalho. O Estado, segundo Sakamoto $(2007)^{2}$ tem uma parcela de culpa, uma vez que fornece condições estruturais e financeiras, além de segurança, para atingir o desenvolvimento econômico em áreas de fronteira agrícola. Proprietários rurais envolvidos em conflitos no campo têm representação política ou participação direta ou indireta nas decisões que dizem respeito ao campo brasileiro.

\section{Conclusões}

O motivo dos dados apontarem tão alarmantes sobre os conflitos trabalhistas podem ser explicados pela contradição que existe no campo brasileiro e que faz parte do seu desenvolvimento capitalista. Baseando-se em Oliveira $(2002)^{3}$, pode-se dizer que há um desenvolvimento contraditório e combinado que, por um lado, cria relações capitalistas mais modernas e, por outro, cria relações não capitalistas de produção e trabalho, sendo que essas relações fazem parte da lógica de desenvolvimento da agricultura brasileira em toda a sua história.

\section{Agradecimentos}

Gostaria de agradecer ao meu orientador, o Prof. Vicente Eudes Lemos Alves pelo apoio e pela presença e ao $\mathrm{PIBIC/CNPq}$ por possibilitar mais esta pesquisa.

\footnotetext{
${ }^{1}$ ALVES, Vicente Eudes Lemos. As novas dinâmicas socioespaciais introduzidas pelo agronegócio nos Cerrados da Bahia, Maranhão, Piauí e Tocantins. In: BERNARDES, J. A.; BRANDÃO FILHO, J. B. (org.). A territorialidade do capital. Rio de Janeiro: Arquimedes Edições, 2009.

${ }^{2}$ SAKAMOTO, Leonardo. A reinvenção capitalista do trabalho escravo no Brasil. In: CPT. Conflitos no campo 2007. p. 110-112.

${ }^{3}$ OLIVEIRA, Ariovaldo Umbelino de. A geografia Agrária e as Transformações Territoriais Recentes no Campo Brasileiro. In CARLOS, Ana Fani Alessandri (org.). Novos Caminhos da Geografia. São Paulo: Contexto, 2002, pp. $63-110$.
} 